Literatus is a journal published by PT Traindo Bangun Negeri, issued two times in one year. Literatus is a scientific publication media in the form of conceptual paper and field research related to general thinking paradigm. It is hoped that Literatus can become a media for academics and researchers to publish their scientific work and become a reference source for the development of science and knowledge.

\title{
Analysis of Sharia Mutual Fund Efficiency with the Data Envelopment Analysis (DEA) Method
}

\section{Analisis Efisiensi Reksa Dana Syariah dengan Metode Data Envelopment Analisis (DEA)}

\author{
Hamzah Robbani \\ Universitas Indraprasta PGRI \\ Jl. Raya Tengah No.80, RT.6/RW.1, Gedong, Kec. Ps. Rebo, Kota Jakarta Timur, Daerah \\ Khusus Ibukota Jakarta 13760
}

\begin{abstract}
According to Lawrence \& Michael, "A portfolio is a collection of investment vehicles assembled to meet a common goal investment" means that the main purpose of the establishment of a portfolio is to obtain optimal results with minimal risk. This study analyzed the efficiency of mutual funds as well as to analyze the differences of each value efficiency sharia mutual fund shares. The results of this study indicate there is one mutual fund sharia efficient during years 2013-2015, namely mutual fund shares of CIMB Principal Islamic Syariah Equity Growth. However, after variance analysis demonstrated no significant differences between the respective values of sharia equity fund. Then the hypothesis Ho is accepted with a value of 0,211 variants. Thus it can be concluded. The efficiency of mutual fund shares for 3 years not describe the significant value of different
\end{abstract}

Keywords: Efficiency, investment, mutual fund, DEA

\section{PENDAHULUAN}

Salah satu instrumen investasi yang mudah dijangkau masyarakat adalah reksa dana. Reksa dana merupakan kumpulan investasi kolektif yang menggunakan jasa manajer investasi sebagai pengelola dana investasi. Menurut UU No.8 tahun 1995 pasal 1 ayat 27 reksa dana didefinisikan sebagai "Wadah yang dipergunakan untuk menghimpun dana dari masyarakat pemodal untuk selanjutnya diinvestasikan dalam portofolio efek oleh manajer investasi". Dari pengertian di atas dapat ditarik kesimpulan bahwa, reksa dana merupakan kumpulan dana dari masyarakat yang diinvestasikan pada saham, obligasi, deposito berjangka, pasar uang, dan lain-lainnya.

Reksa dana syariah secara resmi diluncurkan pada tanggal 14 Maret 2003 bersamaan dengan penandatanganan MOU antara BAPEPAM dengan Dewan Syari'ah Nasional-Majelis Ulama Indonesia. Dengan lahirnya reksa dana syariah terdapat pilihan baru bagi masyarakat dalam melakukan investasi reksa dana.

Pada penelitian yang dilakukan Powers \& Mcmullen, (2000) menyebutkan bahwa sulitnya menentukan pemilihan investasi reksa dana saat terdapat berbagai macam tolak ukur dalam menilai reksa dana tersebut. Maka diperlukan suatu alat analisis yang dapat memberikan penilaian dari banyaknya indikator atau tolak ukur suatu reksa dana. Untuk mendapatkan nilai komposit dari beberapa kriteria tersebut, investor perlu melakukan analisis yang dapat mengukur kriteria-kriteria tersebut menjadi suatu nilai yang bisa menjadi tolak ukur untuk suatu reksa dana. Hal tersebut dapat dilakukan dengan menggunakan metode Data Envelopment Analysis. 
Berdasarkan permasalahan yang dijelaskan di atas, perlu dilakukan penelitian untuk menetapkan struktur investasi pada portofolio reksa dana dengan cara memilih reksa dana yang memiliki tingkat efisiensi tinggi dengan harapan investor dapat meningkatkan nilai investasinya

\section{Data Envelopment Analysis}

Data Envelopment Analysis (DEA) dapat membantu penyelesaian masalah seperti dijelaskan di atas. DEA adalah teknik pengambilan keputusan multi-kriteria yang dapat menentukan portofolio reksa dana yang paling menguntungkan. DEA juga membantu untuk meminimalkan kompleksitas analisis sekaligus mengevaluasi variabel-variabel yang dianggap penting dengan menyajikan satu nilai komposit, sehingga sebuah perhitungan dari berbagai variabel disebut sebagai efisiensi (Powers \& Mcmullen, 2000).

\section{Efisiensi}

Efisiensi dapat didefinisikan sebagai rasio antara output dan input (Kost, 1979). Sedangkan efisiensi dapat didefinisikan sebagai perbandingan antara keluaran (output) dengan masukan (input), atau jumlah keluaran yang dihasilkan dari satu input yang dipergunakan (Permono \& Darmawan, 2000).

Efisiensi dapat didefinisikan sebagai kemampuan organisasi untuk memaksimalkan output dengan menggunakan input tertentu atau menggunakan input secara minimal untuk menghasilkan output tertentu (Muazaroh, Eduardus, Husnan, \& Hanafi, 2012).

\section{Reksa Dana Syariah}

Menurut fatwa DSN No.20/DSN-MUI/IX/2000 reksa dana syariah adalah Reksa Dana yang beroperasi menurut ketentuan dan prinsip syariat Islam, baik dalam bentuk akad antara pemodal sebagai pemilik harta (shahib al-mal) dengan manajer investasi sebagai wakil shahib al-mal, maupun antara manajer investasi sebagai wakil shahib al-mal dengan pengguna investasi.

Sedangkan Darmadji \& Hendy (2006), reksa dana syariah merupakan reksa dana yang mengalokasikan seluruh dana/portofolio ke dalam instrument syari'ah seperti saham-saham yang tergabung dalam JII, obligasi syariah, dan berbagai instrumen keuangan syariah lainnya.

\section{Nilai Aktiva Bersih}

Menurut Samsul (2006) pada hari pertama penawaran umum, unit penyertaan ditawarkan sebagai harga nominal, yaitu Rp1.000 per unit penyertaan (UP), sesuai dengan peraturan dari Bapepam. Pada hari-hari berikutnya harga per UP sudah berubah sesuai dengan perhitungan NAB pada hari bersangkutan. NAB untuk open-end fund wajib diterbitkan setiap hari.

\section{METODE}

Penelitian ini akan menganalisis reksa dana saham syariah yang berada di Indonesia pada periode 2013-2015. Setelah dilakukan analisa efisiensi, untuk membuktikan terdapat perbedaan antara reksa dana yang tergolong efisien dan tidak efisien peneliti melakukan analisis Varian.

Kriteria atau teknik-teknik pengambilan sampel dalam penelitian ini menggunakan metode purposive sampling, maka didapat jumlah sampel yang digunakan dalam 
Literatus is a journal published by PT Traindo Bangun Negeri, issued two times in one year. Literatus is a scientific publication media in the form of conceptual paper and field research related to general thinking paradigm. It is hoped that Literatus can become a media for academics and researchers to publish their scientific work and become a reference source for the development of science and knowledge.

\section{research and development thinking paradigm}

penelitian ini berjumlah tujuh reksa dana saham syariah dengan rincian nama perusahaan reksa dana syariah sebagai berikut:

Tabel 1.

Tanggal Efektif Reksa Dana

\begin{tabular}{ll}
\hline Nama Reksa Dana & Tanggal efekktif \\
\hline PNM Ekuitas Syariah & 26 Juli 2007 \\
Batavia Dana Saham Syariah & 06 Agustus 2007 \\
Mandiri Investa Atraktif Syariah & 16 April 2008 \\
Manulife Syariah Sektoral Amanah Syariah & 22 April 2009 \\
Panin Dana Syariah Saham & 16 Agustus 2012 \\
PNM Ekuitas Syariah & 26 Juli 2007 \\
CIMB-Principal Islamic Equity Growth Syariah & 06 Agustus 2007 \\
\hline
\end{tabular}

Sumber: reksa dana OJK April 2015

Reksa dana saham yang memiliki kriteria seperti yang dijelaskan sebelumnya berjumlah tujuh reksa dana saham syariah yang terdaftar di Otoritas Jasa Keuangan tahun 2013-2015.

Metode analisis yang digunakan dalam penelitian ini adalah Data Envelopment Analysis (DEA). Lalu dilakukan analisis varian untuk mengetahui apakah terdapat perbedaan antara masing-masing nilai efisiensi reksa dana saham syariah.

\section{HASIL DAN PEMBAHASAN}

Hasil

Berikut dipaparkan hasil pengolahan data menggunakan DEA, sebagai berikut:

Tabel 2.

Analisis efisiensi reksa dana 2013 - 2015

\begin{tabular}{lrl}
\hline \multicolumn{1}{c}{ Reksa Dana } & Nilai & Kategori \\
\hline Efisiensi & & \\
2013 Batavia Dana Saham Syariah & 1 & Sangat baik \\
2013 CimB-Principal Islamic Equity Growth Syariah & 1 & Sangat baik \\
2013 Mandiri Investa Atraktif Syariah & 1 & Sangat baik \\
2013 Manulife Syariah Sektoral Amanah & 0,5492 & Baik \\
2013 Panin Dana Syariah Saham & 0,9282 & Sangat Baik \\
2013 PNM Ekuitas Syariah & 0,6807 & Baik \\
2014 Batavia Dana Saham Syariah & 1 & Sangat baik \\
2014 CIMB-Principal Islamic Equity Growth Syariah & 0,9653 & Sangat baik \\
2014 Cipta Syariah Equity & 1 & Sangat baik \\
2014 Mandiri Investa Atraktif Syariah & 0,7831 & Sangat Baik \\
2014 Manulife Syariah Sektoral Amanah & 0,5928 & Baik \\
2014 Panin Dana Syariah Saham & 0,6575 & Baik \\
2014 PNM Ekuitas Syariah & 0,4751 & Cukup \\
2015 Batavia Dana Saham Syariah & 1 & Sangat baik \\
\end{tabular}


2015 CIMB-Principal Islamic Equity Growth Syariah

2015 Cipta Syariah Equity

2015 Mandiri Investa Atraktif Syariah

2015 Manulife Syariah Sektoral Amanah

2015 Panin Dana Syariah Saham

2015 PNM Ekuitas Syariah

\section{1}

0,4410

0,4076

0,3479

0,3458

0,4806
Sangat Baik

Cukup

Cukup

Cukup

Cukup

Rendah vol. 1 , IVO. 1

October 2019,

pp. $25-30$

e-ISSN:

\section{Sumber: diolah}

Analisis varian digunakan untuk mengetahui varian dari beberapa populasi sama atau tidak. Asumsi yang mendasari dalam analysis of varians (ANOVA) adalah bahwa varian dari beberapa populasi adalah sama. Tabel di bawah adalah hasil Analisis Varian (ANOVA) dengan bantuan software SPSS 16.

Tabel 3.

Analisis Varian

\begin{tabular}{llllll}
\hline & Sum of Square & df & Mean Square & F & Sig \\
& & 6 & 0,095 & 1,63 & 0,211
\end{tabular}

Sumber: SPSS 16

Pada Analisis Varian dasar pengambilan keputusan adalah jika nilai Sig > 0,05, pada tabel Nilai varian di atas menunjukkan nilai analisis varian sebesar 0,211 (Ho diterima). Maka dikatakan bahwa varian dari tujuh kelompok populasi data adalah sama. Maka dapat disimpulkan nilai efisiensi tujuh reksa dana saham syariah tidak terdapat perbedaan varian antar efisiensi reksa dana saham syariah.

Setelah dilakukan uji beda analisis varian, peneliti melakukan olah data lanjutan dengan Analisis Multiple Comparation untuk mengetahui perbedaan satu reksa dana terhadap reksa dana lainnya. meskipun telah terbukti tidak terdapat perbedaan dengan menggunakan analisis varian. Nilai efisiensi masing-masing reksa dana memiliki perbedaan secara parsial yaitu antara satu reksa dana dengan reksa dana yang lainnya maka perlu diketahui reksa dana mana yang memiliki perbedaan varian yang Signifikan secara parsial sebagaimana yang dirangkum pada tabel di bawah.

Tabel 4.

Reksa Dana dengan Perbedaan Signifikan

Sumber: data diolah

\begin{tabular}{|c|c|c|c|}
\hline $\begin{array}{l}\text { Kelompok } \\
\text { efisiensi (I) }\end{array}$ & $\begin{array}{l}\text { Kelompok } \\
\text { Efisiensi (j) }\end{array}$ & $\begin{array}{l}\text { Mean } \\
\text { Differen }\end{array}$ & Sig \\
\hline CIMB Islamic & Panin Syariah & 0,4994 & 0,024 \\
\hline CIMB Islamic & $\begin{array}{l}\text { Mandırı } \\
\text { Syariah }\end{array}$ & 0,4834 & 0,028 \\
\hline
\end{tabular}

Tabel tersebut menunjukkan reksa dana CIMB-Principal Islamic Equity Growth Syariah memiliki perbedaan yang signifikan pada reksa dana Panin Dana Syariah Saham dengan nilai 0,4994. Lalu CIMB-Principal Islamic Equity Growth Syariah juga memiliki perbedaan signifikan dengan reksa dana Mandiri Investa Atraktif Syariah dengan nilai 0,4834.

\section{Pembahasan}

Pada penelitian ini, alat analisis yang digunakan yaitu Data Envelopment Analysis dengan metode Contstan Variabel to scale. AAM (2013) menjelaskan Model constant return to scale dikembangkan oleh Charnes, Cooper dan Rhodes (Model CCR) pada tahun 1978. Model ini mengasumsikan bahwa rasio antara penambahan input dan output adalah sama 


\section{LITERATUS}

research and development thinking paradigm

Literatus is a journal published by PT Traindo Bangun Negeri, issued two times in one year. Literatus is a scientific publication media in the form of conceptual paper and field research related to general thinking paradigm. It is hoped that Literatus can become a media for academics and researchers to publish their scientific work and become a reference source for the development of science and knowledge.

Our focus:

Social and Culture

Our Scope:

Humanities,

Education,

Management,

History,

Economics,

Linguistics,

Literature,

Religion

Politics,

Sociology,

Anthropology,

and others.

(constant return to scale). Artinya , jika ada tambahan input sebesar x kali, maka output akan meningkat sebesar x kali juga. Asumsi lain yang digunakan dalam model ini adalah bahwa setiap perusahaan reksa dana atau unit pembuat keputusan (UPK) beroperasi pada skala yang optimal. Adapun Data Envelopment Analysis dengan metode Variabel Return to Scale (VRS) merupakan pengembangan dari metode VRS Model ini beranggapan bahwa perusahaan tidak atau belum beroperasi pada skala yang optimal.

Penelitian dengan metode CRS menghasilkan nilai efisiensi rata-rata dari ketujuh reksa dana saham syariah selama periode 3 tahun sebesar 0,7166 dengan skala baik. Hal tersebut memberikan gambaran umum bahwa reksa dana saham syariah di Indonesia rata-rata sudah memiliki nilai efisiensi yang baik. Hal tersebut dikarenakan infrastruktur investasi yang dibangun dengan baik. Peranan manajer investasi dalam menempatkan dana modal pada saham-saham dan instrumen investasi memiliki nilai return yang baik sehingga hal-hal yang bersifat beban seperti biaya dan risiko dapat diminimalisasi. Nilai efisiensi reksa dana saham syariah yang sebelumnya diungkapkan memerlukan analisis yang lebih dalam dengan memilih reksa dana saham syariah mana yang paling efisien. Pada hasil penelitian ini ditunjukan bahwa terdapat satu reksa dana saham syariah yang konsisten berada pada nilai efisiensi $100 \%$ selama tiga tahun periode penelitian yaitu CIMB-Princippal Equity Growth Syariah. Hal tersebut dapat menjadi rujukan bagi investor dalam memilih reksa dana saham syariah mana yang berada pada posisi efisien. Bagi manajer investasi CIMB-Principal Equity Growth Syariah dapat menjadi rujukan dari segi stoock selection, alokasi dana kelolaan menjadi faktor utama tingkat return pada reksa dana saham syariah.

Selain CIMB-Principal Equity Growth Syariah reksa dana yang memiliki skala efisiensi sangat baik yaitu Batavia dana saham syariah dengan nilai 0,79 dan PNM ekuitas syariah dengan nilai 0,86 . Selain itu terdapat tiga reksa dana saham syariah yang memiliki skala efisiensi baik yaitu Cipta Syariah Equity dengan nilai 0,74, Mandiri Investa Atraktif Syariah dengan nilai efisiensi 0,52, dan Manulife Syariah Sektoral Amanah sebesar 0,64. Lalu terdapat satu reksa dana yang berada pada skala efisinesi rendah yaitu Panin Dana Syariah Saham sebesar 0,50.

Sebagaimana penelitian yang dilakukan Manurung (2000) setelah dilakukan analisis efisiensi. Dilakukan analisis uji beda untuk mengetahui signifikan perbedaan masing-masing nilai reksa dana. Sebelum melakukan analisis uji beda, peneliti melakukan uji normalitas data sebagai syarat untuk melakukan analisis uji beda. Dengan menggunakan SPSS 16 uji normalitas dilakukan dengan teknik Kolmogorov Smirnov. Hasil pengolahan uji normalitas menunjukkan data terdistribusi normal dengan nilai 0,829 pada tahun $2013,0,616$ pada tahun 2014, dan 0,979 pada tahun 2015. Sebagaimana diketahui syarat uji normalitas data nilai signifikan harus berada di atas 0,05. Maka data pada penelitian ini terbukti normal untuk dapat dilakukan analisis uji beda.

Pada penelitian ini diketahui nilai signifikan hasil pengolahan data dengan menggunakan SPSS 16 sebesar 0,211 yang berarti tidak cukup bukti untuk menolak H0. Dengan begitu $\mathrm{HO}$ diterima yang berarti tidak ada perbedaan varian antara masing-masing reksa dana.

Namun setelah dilakukan pengolahan data lanjutan dengan menggunakan post hoc didapatkan perbedaan signifikan nilai reksa dana antara CIMB-Principal Equity Growth Syariah dengan Panin Dana Syariah Saham sebesar 0,024 dengan mean different 0,4994 yang berarti reksa dana CIMB-Principal Equity Growth Syariah lebih besar dari Panin Dana Syariah Saham dengan nilai perbandingan 0,4994. Lalu CIMB-Principal Equity Growth Syariah juga terdapat perbedaan signifikan dengan reksa dana Mandiri Investa Atraktif Syariah dengan nilai signifikan 0,028 dan nilai mean different sebesar 0,4834 yang berarti CIMB-Principal Equity Growth Syariah lebih besar dari Mandiri Investa Atraktif Syariah dengan nilai perbandingan 0,4834 .

Pada analisis regresi, hasil pengolahan data menggunakan SPSS 16 menunjukkan hasil persamaan: $\mathrm{Y}=0,620-0,181+0,075+0,315$

Hal tersebut menunjukkan bahwa standar deviasi berkolerasi negatif dengan nilai return. Sedangkan nilai biaya lain lain dan biaya investasi berkolerasi positif yang berarti peningkatan biaya tersebut dapat meningkatkan kinerja reksa dana yang pada akhirnya dapat 
meningkatkan return pada analisis regresi kedua memberikan hasil dengan persamaan: $\mathrm{Y}=$ $\mathrm{a}-0,385+0,081+0,220+0,391$

Hal tersebut menunjukkan bahwa standar deviasi berkolerasi negatif dengan nilai return. Sedangkan nilai biaya lain-lain, biaya investasi dan return berkolerasi positif yang berarti peningkatan biaya dan return dapat meningkatkan kinerja reksa dana yang pada akhirnya dapat meningkatkan nilai efisiensi reksa dana.

Vol. 1, No. 1

October 2019,

pp. 25-30

e-ISSN:

2686-5009

\section{PENUTUP}

Dari penelitian yang dilakukan, dapat disimpulkan dari 7 reksa dana saham syariah hanya satu reksa dana saham syariah yang mencapai nilai efisien selama tiga tahun yaitu CIMB-Principal Islamic Equity Growth Syariah dan terdapat tiga reksa dana lainya yang memiliki nilai efisien 100\% pada tahun 2013 yaitu PNM Ekuitas Syariah, Cipta Syariah Equity, dan Batavia Dana Saham Syariah. Pada tahun 2014 terdapat dua reksa dana saham syariah yang mencapai nilai efisien $100 \%$ yaitu Cimb-Principal Islamic Equity Growth Syariah dan PNM Ekuitas Syariah, dan pada tahun 2015 terdapat satu reksa dana saham syariah yang mencapai nilai efisien $100 \%$ yaitu Cimb-Principal Islamic Equity Growth Syariah.

Pada periode tiga tahun penelitian, terdapat reksa dana saham yang inefisien, Hal tersebut dipengaruhi oleh total biaya yang meningkat terutama pada biaya total. Untuk memastikan perbedaan antara nilai reksa dana saham syariah, peneliti melakukan Analisis Varian. Hasil analisis varian dengan menggunakan Bantuan software spss 16 menunjukan nilai varian 0,211 yang artinya tidak terdapat perbedaan antara nilai efisiensi masing masing reksa dana saham syariah periode 2013 - 2015. Hal tersebut membuktikan bahwa hipotesis Ho diterima. Namun pada pengolahan data lanjutan dengan menggunakan post hoc multiple comparation didapati perbedaan signifikan pada reksa dana CIMB-Principal Islamic Equity Growth Syariah terhadap Panin Dana Syariah Saham dan Mandiri Investa Atraktif

\section{DAFTAR PUSTAKA}

Darmadji, T., \& Hendy, M. F. (2006). Pasar Modal di Indonesia Pendekatan Tanya Jawab. Jakarta: Salemba Empat.

Kost, F. E. (1979). Organization and Management. A System and Contingency Approach. United States: McGraw-Hill Inc.

Manurung, I. H. (2000). Penerapan Data Envelopment Analysis (DEA) untuk Mengukur Efisiensi Kinerja. Indonesia: library.telkomunivversity.ac.id.

Samsul, M. (2006). Pasar modal dan manajemen portofolio. Jakarta: PT. Gelora Aksara Pratama.

Muazaroh, Eduardus, T., Husnan, S., \& Hanafi, M. M. (2012). Determinant of Bank Profit Efficiency: Evidence from Indonesia. International Journal of Economics and Finance Studies, 4(2), 163-173. Retrieved from https://dergipark.org.tr/tr/download/article-file/256649

Permono, I. S., \& Darmawan. (2000). Analisis Efisiensi Indrustri Perbankan di Indonesia ( Studi Kasus Bank-Bank Devisa di Indonesia Tahun 1991-1996 ). Jurnal Ekonomi Dan Bisnis Indonesia, 15(1), 1-13. Retrieved from https://jurnal.ugm.ac.id/jieb/article/download/39324/22267

Powers, J., \& Mcmullen, P. R. (2000). Using Data Envelopment Analysis to Select Efficient Large Market Cap Securities. Journal of Business and Management, 7(2), 31-42. Retrieved from https://pdfs.semanticscholar.org/48dc/8bd8199b03621c1039e33bc73e7d69d803c8.p df 